\title{
Short and Long-term Asymmetric Farm-Retail Price Transmission Analysis in the Canadian Agri-food Industry: Evidence from Dairy and Pork Sectors with Threshold Cointegration Models
}

\author{
Baoubadi Atozou ${ }^{1}$, Kotchikpa Gabriel Lawin ${ }^{2}$, Aristide Bonsdaouende Valea ${ }^{3} \&$ Sirine Aouini ${ }^{3}$ \\ ${ }^{1}$ Food and Agriculture Organization of the United Nations (FAO), Italy \\ ${ }^{2}$ International Fund for Agricultural Development (IFAD), Research and Impact Assessment (RIA), Italy \\ ${ }^{3}$ Center for Research on the Economics of the Environment, Agri-food, Transports and Energy (CREATE), Laval \\ University, Canada \\ Correspondence: Baoubadi Atozou, Circonvallazione Ostiense 236, 00154 Rome, Italy. Tel: 39-349-499-1680. \\ E-mail: atozoubaoubadi@gmail.com
}

Received: January 24, 2019

Accepted: February 15, 2019 Online Published: March 1, 2019

doi:10.5539/jfr.v8n2p66

URL: https://doi.org/10.5539/jfr.v8n2p66

\begin{abstract}
Empirical studies show that market concentration and pricing policies regulation have an important impact on price transmission. These factors lead to an asymmetric price transmission, particularly in agricultural commodities markets. This paper investigates farm-retail price transmission along the Canadian dairy and pork values chains using Threshold Autoregressive, Momentum Threshold Autoregressive, Error Correction Models and Granger causality test. Using monthly price data, we found that farm-retail price transmission is asymmetric in short and long-term between raw milk and butter price while it is symmetric in the cheese case. In the pork sector, price transmission is asymmetric in long-term and symmetric in short-term between farm price and respectively pork chops and bacon prices. Because of processor and retailer concentration, consumer prices respond more quickly to upward than downward of farm prices. The processors, retailers and distributors concentration along the value chain in Canadian dairy and pork sectors and the supply management regulation policies as well as income stabilization insurance program are the main factors generating this market structure. Consideration of the characteristics of farmers, processors, and retailers in the value chain and the actors' potential reactions to the agricultural policy could better protect consumers and producers from market distortion.
\end{abstract}

Keywords: asymmetric price transmission, Canadian dairy and pork's value chain, market power, threshold error correction model

JEL codes: Q13, C22, D4

\section{Introduction}

Agri-food industries in most countries are marked by a high concentration of processors and retailers (Sexton, 1990). This concentration is often perceived as a source of market power for these intermediaries, who are able to capture a large part of the margin resulting from a possible prices variation. The exercise of this market power is manifested by the ability of intermediaries to transmit the input price increases quickly and totally to the consumer. In contrast, declines in input prices are partially transmitted and at a slower rate than price increases (von Cramon-Taubadel, 1998).

This phenomenon called "asymmetric price transmission" has some implications for economic policies outcomes. On the one hand, consumers do not fully benefit from input price reductions, while producers, on the other hand, do not benefit from consumer price increases (Meyer and von Taubadel, 2004). According to Vavra and Goodwin (2005), when price transmission is not total and symmetric, trade liberalization effects on consumer welfare are overestimated.

Price dynamic analysis in agri-food industry was a major preoccupation for policy-makers, agri-food firms, and consumers. Several authors such as Kinnucan and Forker (1987), Cramon-Taubadel (1997), Goodwin and Harper (2000), Bakucs and Ferto (2005), Carman and Sexton Cotterill (2005), Lass (2005), Jensen and Moller 
(2007), Kim and Ward (2013), and Riziti (2014) were interested in price transmission down the value chain of agri-food products such as dairy, poultry, pork, beef, wheat, corn and fish. Goodwin and Happer (2000), Cutts and Kirsten (2006), Asche et al. (2007), Rojas et al. (2008) used econometric models to test farm-retail price asymmetry transmission in the agri-food industry. Error corrected models and threshold cointegration tests are widely used in such investigations. Ben-Kaabia and Gil (2007) studied the contagion of shocks between farm and retail prices in the lamb sector in Spain. Using the three-regime autoregressive model, their results suggest that price transmission is perfect in long run and the supply and demand shocks are fully transmitted throughout the production chain. In the short-term, however, transmission between producers and retailers is asymmetric. Awokuse and Wang (2009) using the threshold error correction model have shown that price transmission between farm and retail is asymmetric in the case of butter and fluid milk in United States, and symmetric for cheese.

Using monthly data, Anders (2008), analyzed the degree of oligopsony and oligopoly market power in Germany's food distribution industry. The results showed strong oligopoly and oligopsony market power in the retail market for pork between 1995 and 2000. Retailers or processors market power according to McCorriston et al. (2001), and Awokuse and Wang (2009) induce an imperfect price transmission resulting in fall of farm prices and may lead to an increase in the rent of downstream firms.

Several authors showed that asymmetric price transmission factors in agri-food supply chains are strongly related to the concentration of downstream firms and therefore to market power held by intermediaries (Lloyd et al., 2006; Assefa et al., 2014). These market failures lead downstream firms to keep prices higher even during periods of input prices decrease.

Market failures are encountered in the agri-food sectors of most Canadian provinces. Indeed, the agricultural sectors are composed of large numbers of producers or farms against small numbers of processors and retailers. Three major processors account for $83 \%$ of the fluid milk market, according to the Canadian Dairy Information Center (Note 1). In the retail market in Quebec, three large companies accounted for $69 \%$ of the food distribution market in 2010 (Petit, 2014): Loblaws / Provigo, Sobeys / IGA and Metro. Such a market structure is likely to be a source of market power exercise by processors and retailers to the detriment of producers and consumers, it is necessary, so, to examine the nature of price transmission in this sector, especially in a context of liberalization where Canada is increasingly involved in free trade agreements.

The pork sector is one of Canada's largest suppliers of agricultural export products. In addition, milk is the main supply managed products in terms of production value. This study focuses on these two sectors for the aforementioned reasons. The results will allow comparative analyzes of price transmission between supply managed sectors and those that are not. This study contributes significantly to the empirical literature on price transmission in the Canadian agri-food sector for which, to the best of our knowledge, there are not enough investigations (Note 2).

The rest of the paper is organized as follows. The first section presents the market structure and agricultural policy in Canadian milk and pork industries. The second section presents the econometrics approaches. The third presents the data and descriptive analysis. The results and discussions are presented in sections four and five respectively, and Section six concludes.

\section{Market Structure and Agricultural Policy in Canadian Milk and Pork Industries}

\subsection{Agricultural Policy in Milk Sector}

The volatility of agricultural commodity prices in the 1960s prompted Canada to adopt a supply management policy for certain commodities - poultry, eggs and dairy products (Heminthavong, 2015). This policy consists of controlling production and imports in order to provide producers with stable incomes. Production and import quotas are the main tools used to achieve this objective (Skogstad, 1993).

One of the current debates on supply management is the very high price of the products concerned compared to the prices that would prevail without this policy (Lippert, 2001). For the dairy sector in particular, the Canadian Dairy Commission is responsible for fixing the prices of homogeneous milk and also sets prices for dairy products on the basis of production costs (Heminthavong, 2015). However, retails dairy product prices are administered in each province policy and in Canada in general. For example, in Quebec, the milk-retail prices are administered: dairy processors, distributors and retailers apply to the Régie des marchés agricoles et alimentaires du Quebec (RMAAQ) for an increase (Note 3). In such a producer price-setting mechanism and retailers price administration, it should theoretically be expected that the price transmission between the different dairy products, on the one hand, and fluid milk, on the other hand, is symmetrical. Nevertheless, negotiation 
times can induce a delay and asymmetric transmission of shocks between producer and retail prices.

\subsection{Agricultural Policy and Market Structure in Pork Sector}

Canada's pork industry is comprised of pork producers, slaughter companies, processors and distribution industries. In 2014, Canadian pork production covered more than 268\% of domestic demand (MAPAQ, 2014). This sector is open to international trade. Since 2011, Canada has accounted for $7 \%$ of the international pork market (MAPAQ, 2014). Quebec is the largest exporter in Canada, accounting for $42 \%$ of the total value of Canada's exports of pork products in 2014 and the fifth-largest exporter in the world (MAPAQ, 2014). In 2014, $20 \%$ of Quebec production was sold on the local market, $13 \%$ on the rest of Canada and $67 \%$ sold on the international market (MAPAQ, 2014).

In Canada, the number of pork farms has decreased by $9 \%$ between 2010 and 2014, compared to an increase of $13 \%$ in hogs per farm (MAPAQ, 2014). This situation shows a progressive tendency to concentrate the link of production on the farm. The hog slaughter market is concentrated in Canada as well as in Quebec. In fact, in Quebec, 12 federally inspected companies slaughter 99\% of hogs in Quebec, and 10 of them integrate all the activities of the chain, namely production, slaughter and processing (MAPAQ, 2014). In Quebec, the pork sector is covered by the Agricultural Income Stabilization Insurance Program. Atozou and Lawin (2016) showed that this program leads to a disconnection between production decisions and market conditions, thus generating overproduction regardless of the market price.

The supply of pork being surplus, the pork' price can decrease. As a result, this agricultural program may have a negative effect on the prices of pork products in grocery market in Canada given the integration of trade between provinces. Consumers may benefit from this program because of lower prices for pork products. In addition, as the pork sector is open to the international market, the surplus generated by the program could be totally exported, leaving internal prices stable or rising. Three major Loblaws / Provigo, Sobeys / IGA and Metro spheres share $68.4 \%$ of the Quebec food distribution market (Note 4) and four groceries (Loblaw, Empire Co. Ltd., Walmart Supercenter and Metro Inc.) share 56\% of the market in Canada (Note 5).

Given the increasing concentration of producer links, slaughter enterprises, vertical business integration, and the effects of Farm Income Stabilization Insurance Program, we hypothesize that the increase in pork price, results in a rapid and complete transmission to retail prices. On the other hand, a decrease in pork's price is slowly and partially transmitted to retail prices.

\section{Materials and Methods}

\subsection{Granger Causality Test}

The Granger causality test (1988) is defined between two variables: the farm's and retail's commodities price noted respectively as $P P$ and $P R$. The two variables are stationary at the first difference. This causality test starts from the presentation of the following autoregressive Vector model:

$$
\begin{gathered}
\Delta P P_{t}=\delta_{0}+\sum_{i=1}^{k} \delta_{i} \Delta P P_{t-i}+\sum_{j=1}^{k} \gamma_{j} \Delta P R_{t-j}+\mu_{1 t} \\
\Delta P R_{t}=\beta_{0}+\sum_{i=1}^{k} \beta_{i} \Delta P R_{t-i}+\sum_{j=1}^{k} \zeta_{j} \Delta P P_{t-j}+\mu_{2 t}
\end{gathered}
$$

With $\mu_{1 t}$ and $\mu_{2 t}$ are white noise error terms and non-autocorrelated, and $P P_{t}$ and $P R_{t}$ the farm and retail' prices at time t. These series are supposed to be integrated in order one. Then:

$>\Delta P R_{t}$ Granger caused $\triangle P P_{t}$ if at least one of the coefficients $\gamma_{j}$ in equation (1) is statistically different from zero and all coefficients $\zeta_{j}$ of equation (2) are statistically nonsignificant (unidirectional causality).

$>\Delta P P_{t}$ Granger caused $\triangle P R_{t}$ if at least one of the coefficients $\zeta_{j}$ in equation (2) is statistically different from zero and all coefficients $\gamma_{j}$ of equation (1) are statistically null (unidirectional causality)

$>\triangle P R_{t}$ Granger caused $\triangle P P_{t}$ and simultaneously $\triangle P P_{t}$ Granger $\triangle P R_{t}$ if at least one of the coefficients $\gamma_{j}$ of equation (1) and at least one of the coefficients $\zeta_{j}$ of equation (2) are statistically different from zero (bidirectional causality).

$>$ If none of the coefficients $\gamma_{j}$ of equation (1) and none of the coefficients $\zeta_{j}$ in equation (2) is significant, then the variables are independent.

We use the Wald test to examine the hypotheses of the Granger causality test.

\subsection{Engel and Granger Cointegration Test}

Engel and Granger (1987) constructed a test to determine whether there is a linear long-run equilibrium relationship between a given set of two variables. According to these authors, the components of a vector of 
variables $X_{t}$ are called cointegrated of order d, b denoted $X_{t} \sim C I(d, b)$ if: (I) all variables of the vector $X_{t}$ are all of order $d$, and (ii) that there is a vector $\alpha(\neq 0)$ of parameters such that the relationship $h_{t}=$ $\alpha X_{t} \sim I(d-b), b>0$. The vector $\alpha$ is called the cointegration vector coefficients. In our study, the variable vector is composed of two prices series: the consumer price index $P R_{t}$ and the farmer price $P P_{t}$ in time t.

The stationary tests of the two variables will be analyzed through the Dickey-Fuller Augmented test by Dickey and Fuller (1981) and the Phillips-Perron test (1988). If the two variables are I(1), then the study of the cointegration relation according to the principle of Engel and Granger (1987) is done in two stages: the first step consists in regressing the following equation:

$$
P C_{t}=\delta_{0}+\delta_{1} P P_{t}+u_{t}
$$

Where error term $u_{t}$ represents the imbalance between the retail price and the producer price (Ewing et al., 2006) and $u_{t} \sim I(1)$ according to Engel and Granger (1987). The last step to analyze the first order autocorrelation of the error term (Engel and Granger 1987, Ewing et al., 2006). The following equation is regressed:

$$
\Delta P C_{t}=\gamma \Delta P P_{t}+\rho_{1} \hat{\mathrm{u}}_{t-1}+v_{t}
$$

Where error term $v_{t}$ is white noise, independent and identically distributed $\left(v_{t} \sim \operatorname{IID}\left(0, \sigma^{2}\right)\right.$. There is a cointegration relationship between consumer price and producer price if the parameter $\rho_{1} \mathrm{~s}$ statistically different from zero $\left(\rho_{1} \neq 0\right)$ and negative. Then the error-correction model is as follows (Engel and Granger, 1987).

$$
\Delta P C_{t}=\sum_{i=1}^{p} \varphi_{1} \Delta P P_{t-i}+\sum_{i=1}^{p} \theta_{1} \Delta P C_{t-1}+\delta\left(P C_{t-1}-a P P_{t-1}-b\right)+\epsilon_{t}
$$

where the error term $\epsilon_{t}$ is a white noise, $\delta$ the fitting speed which is significantly negative, $(\mathrm{a}, \mathrm{b})$ the cointegration relationship vector coefficients. The parameters $\varphi_{i}$ and $\theta_{i}$ represent the short-term effects between the two variables. This model is constructed under the assumption that there is perfect symmetry in the adjustment to the equilibrium between the variables.

Enders and Siklos (2001) proposed an extension of this Engel-Granger error correction model by allowing asymmetry in the two-way equilibrium adjustment (fall or rise). These authors have demonstrated that this extension has more power than the classic strategy of Engel and Granger (1987) when there is a possibility of adjustment asymmetry between the variables. In the absence of asymmetry adjustment to equilibrium, this extension gives the same results as the basic model of Engel and Granger (1987).

\subsection{Threshold Error Correction Model}

In our analysis, we adopt the models developed by Enders and Siklos (2001) to examine short-term and long-term price transmission asymmetry in Canadian's agri-food industry. Nevertheless, the error correction model of Engel and Granger (1987) (see appendix) is our benchmark model. This model is based on an assumption of symmetric price transmission. The literature shows that price transmission is mostly asymmetrical in agri-food markets because of the high concentration of downstream firms and their holding of market power (Lloyd and al., 2006; Bakucs and al., 2014; And Assefa and al., 2014). Then the use of Enders and Siklos's Threshold Autoregressive (TAR) and Momentum-Threshold Autoregressive (M-TAR) models is more appropriate in the analysis of this issue in this context (Atozou and Akakpo, 2017).

Either the long-term relationship between retail and farm prices represented by the following equation:

$$
R P_{t}=\alpha_{0}+\alpha_{1} P P_{t}+n_{t}
$$

Where $R P_{t}$, and $P P_{t}$ are steady in first difference (I(1)) and $\alpha_{i}$ are the estimated parameters and $n_{t}$ is the disturbance error term that may be serially correlated (Enders and Siklos, 2001). The latter are based on the two-stage method of Engels and Granger (1987) which consists in estimating the above model by the least ordinary square and obtaining the residuals $\hat{n}_{t}$. The second step is to estimate the following model:

$$
\Delta \hat{n}_{t}=\pi \hat{n}_{t-1}+\omega_{t}
$$

Where $\omega_{t}$ is the white noise error term. The non-rejection of the alternative hypothesis of the presence of the cointegration relation between the variables $(-2<\pi<0)$ implies that the residues $\hat{n}_{t}$ are stationary and of zero mean (Enders and Siklos, 2001). The latter then propose an alternative specification of the error-corrected model called Threshold Autoregressive (TAR) model arising from the specification of the second-step equation of Engel and Granger (see Appendix):

$$
\Delta \hat{n}_{t}=I_{t} \pi_{1} \hat{n}_{t-1}+\left(1-I_{t}\right) \pi_{2} \hat{n}_{t-1}+z_{t}
$$


Where $I_{t}$ is an indicator function given by:

$$
I_{t}= \begin{cases}1 & \text { if } \hat{n}_{t-1} \geq \tau \\ 0 & \text { if } \hat{n}_{t-1}<\tau\end{cases}
$$

Where $\tau$ the threshold is determined according to the algorithm developed by Chan (1993) and $z_{t}$ is a white noise, independent and identically distributed error term variable such that $z_{t}$ is independent of $\hat{n}_{t}$. The residual series $\hat{n}_{t}$ is stationary if the following necessary and sufficient conditions are satisfied:

$$
\left\{\begin{array}{c}
\pi_{1}<0 \\
\pi_{2}<0 \\
\left(1+\pi_{1}\right)\left(1+\pi_{2}\right)<1
\end{array} \text { for any threshold value } \tau\right.
$$

The adjustment is symmetric if $\pi_{1}=\pi_{2}$ Which corresponds to the classic model of Engel and Granger. The Threshold Autoregressive (TAR) model is then specified as follows:

$$
\Delta R P_{t}=\sum_{i=1}^{p} \varphi_{1} \Delta P P_{t-i}+\sum_{i=1}^{p} \theta_{1} \Delta R P_{t-1}+I_{t} \pi_{1} \hat{n}_{t-1}+\left(1-I_{t}\right) \pi_{2} \hat{n}_{t-1}+\sum_{i=2}^{p} \gamma_{i} \hat{n}_{t-i}+\epsilon_{t}
$$

The speed of adjustment to long-term equilibrium is $\pi_{1}$ if $\hat{n}_{t-1}$ is above the equilibrium and $\pi_{2}$ if it is below the long-term relationship. The value of the threshold is unknown and must be estimated. This threshold is estimated according to Chan's algorithms that corresponds to one of the $70 \%$ of the central values of the residuals which minimizes the information criterion of the threshold cointegration equation. Generally, it is appropriate to assume that the value of the threshold is equal to zero $(\tau=0)$ as in Engels and Granger model.

When the residual series $\hat{n}_{t}$ presents more dynamics in one direction than the other, M-TAR model is used to analyze the process of volatility transmission between variables. The M-TAR model's specification is the same as TAR model, the single difference lies to the indicator function specification which is given by:

$$
I_{t}= \begin{cases}1 & \text { if } \Delta \hat{n}_{t-1} \geq \tau \\ 0 & \text { if } \Delta \hat{n}_{t-1}<\tau\end{cases}
$$

To capture short-term price transmission, $\Delta P P_{t-i}$ is broken down into two variables that characterize the negative and positive variability of farm price:

$$
\Delta P P_{t-i}^{+}=\left\{\begin{array}{rr}
\Delta P P_{t-i} \text { si } \Delta P P_{t-i}>0 \\
0 & \text { otherwise }
\end{array} \text { et } \Delta P P_{t-i}^{-}=\left\{\begin{array}{rr}
\Delta P P_{t-i} \text { si } \Delta P P_{t-i}<0 \\
0 & \text { otherwise }
\end{array}\right.\right.
$$

Where $\Delta P P_{t-i}^{+}$and $\Delta P P_{t-i}^{-}$represent respectively the rise and fall in farm prices. Thus, the model of threshold cointegration equation (TAR model) becomes:

$$
\Delta R P_{t}=\sum_{i=1}^{p} \varphi_{i}^{+} \Delta P P_{t-i}^{+}+\sum_{i=1}^{p} \varphi_{i}^{-} \Delta P P_{t-i}^{-}+\sum_{i=1}^{p} \theta_{1} \Delta R P_{t-1}+I_{t} \pi_{1} \hat{n}_{t-1}+\left(1-I_{t}\right) \pi_{2} \hat{n}_{t-1}+\sum_{i=2}^{p} \gamma_{i} \hat{n}_{t-i}+\epsilon_{t}
$$

Coefficients $\varphi_{i}^{+}$and $\varphi_{i}^{-}$describe the short-term impact of farm price changes on the retail price. The hypothesis of the symmetric short price transmission is verified if there is equality between the two types of short-term coefficients for each $i, i=1, \ldots, P$.

\section{Data and Descriptive Statistics}

The retail price data used in this article was gathered from CANSIM files of Statistics Canada while the farm prices come from FAO website. The data represent monthly average price of retail and farm commodities. Eight agricultural commodities are used for analysis; raw milk, pork, homogenous milk, partially skimmed milk, butter, cheese, pork chop and pork bacon. The data represent a five-year period 2010(1)-2014(12) or a total of 60 observations. We present in table 1 , the descriptive statistics on the data series used in the analysis. 
Table 1. Descriptive statistics

\begin{tabular}{llllllll}
\hline & Min & Mean & Max & SD & Med. & CV & Skewness \\
\hline Producer price (Nominal) & & & & & & & \\
Raw milk (\$/ton) & 703.00 & 749.70 & 798.00 & 26.00 & 748.00 & 0.03 & 0.08 \\
Pork (\$/ton) & 1055.00 & 1484.10 & 2242.00 & 262.00 & 1431.00 & 0.18 & 1.18 \\
Retail price (Nominal) & & & & & & & \\
Pork chop (\$/kg) & 9.02 & 10.70 & 13.05 & 1.04 & 10.50 & 0.10 & 0.85 \\
Pork bacon (\$/kg) & 4.51 & 5.29 & 6.91 & 0.61 & 5.14 & 0.12 & 1.52 \\
Homogenous milk (\$/liter) & 2.19 & 2.37 & 2.49 & 0.09 & 2.40 & 0.04 & -0.53 \\
Partially skimmed milk (\$/liter) & 2.12 & 2.26 & 2.34 & 0.07 & 2.29 & 0.03 & -0.79 \\
Butter (\$/454g) & 4.17 & 4.37 & 4.58 & 0.10 & 4.37 & 0.02 & 0.07 \\
Cheese (\$/250g) & 2.66 & 2.79 & 2.98 & 0.06 & 2.79 & 0.02 & 0.55 \\
\hline Observations & 60 & & & & & & \\
\hline
\end{tabular}

Note: SD indicates "Standard Deviation"; Med. indicates "Median"; CV indicates "Coefficient of Variation"

The coefficient of variation in table 1 shows the price volatility in each sector. The table 1 shows that the pork producer price is more volatile than retail price. The prices in the milk industry are somehow stable. However, the farm price is less volatile than retail prices. Comparison across industry shows that price is more volatile in the pork industry than in milk industry as the coefficients of variation are higher for pork prices. This is not surprising since the milk industry is under supply management policy which aims at stabilizing the price in that industry. We show in Figure 1 and Figure 2 the price trends in the milk and pork industry respectively.

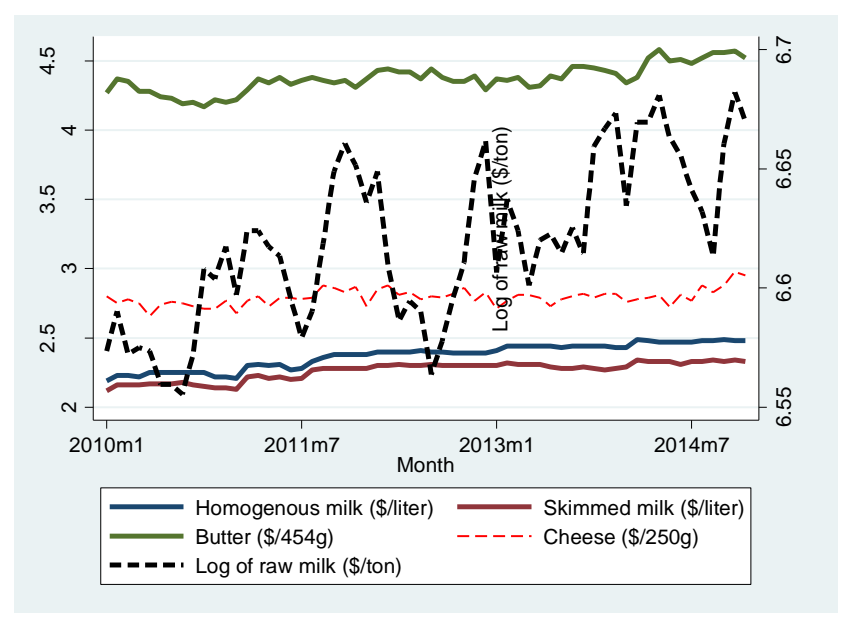

Figure 1. Price trends in the milk industry

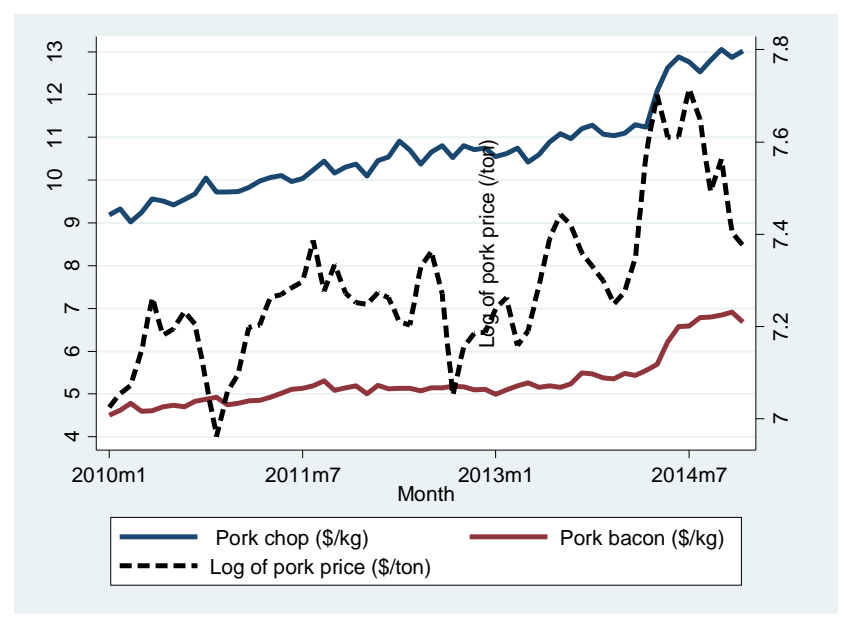

Figure 2. Price trends in the pork industry 
Figure 3 shows the kernel density of the log of the price of each of the eight agricultural commodities considered in the article. The Figure 1 shows that none of the price of the eight agricultural commodities has a symmetric distribution (the skewness are all different from zero). Milk and Pork producer prices are skewed to the right meaning that prices volatility was in favor of the produces. Figure 3 also shows a positively skewed distribution for the retail price of butter, cheese, pork chop and pork bacon. Hence, price volatility made retailers better off. In contrast, the distribution of the price of homogenous milk and partially skimmed milk are negatively skewed showing that consumers were favored by the price volatility.

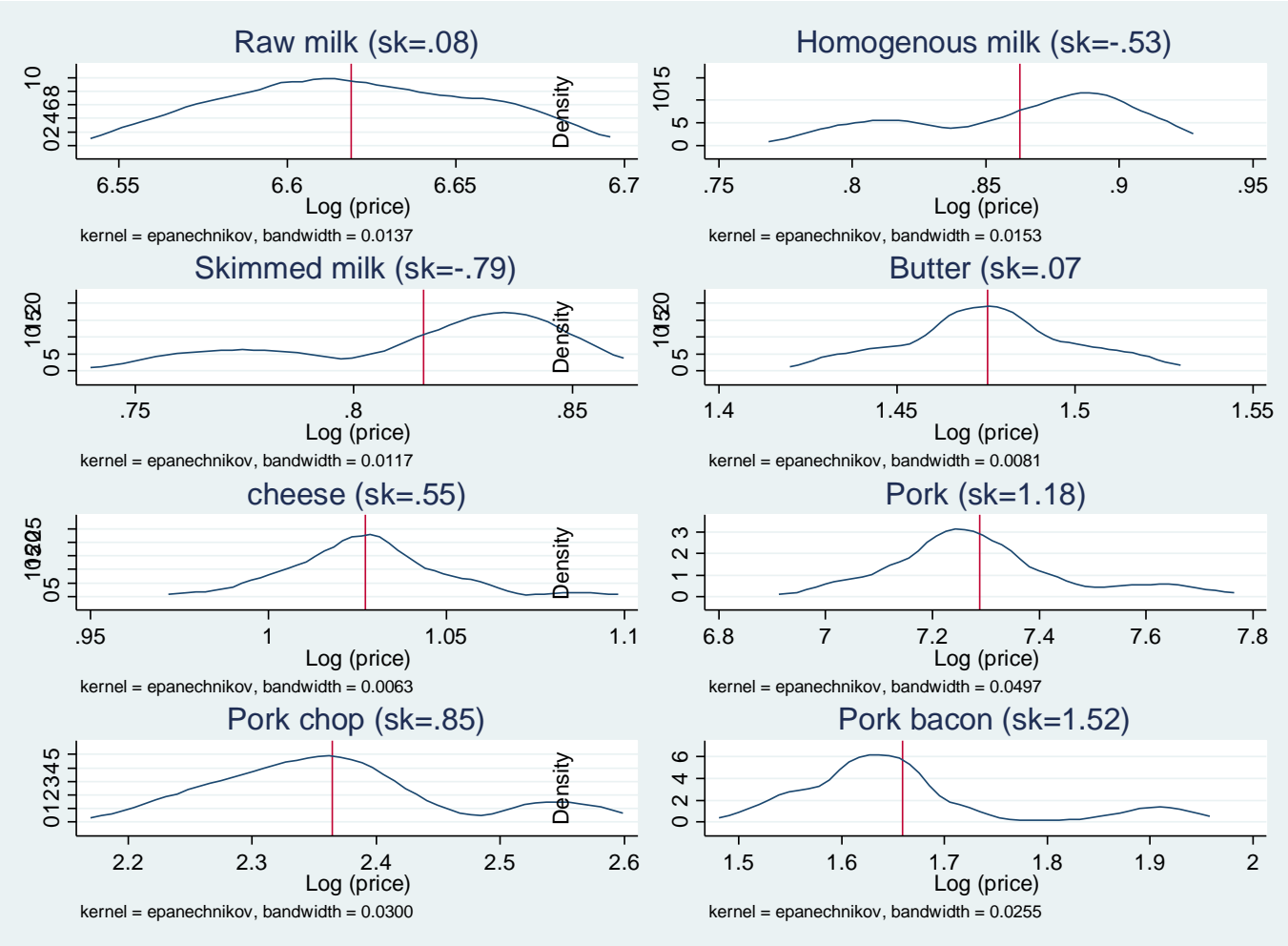

Figure 3. Kernel density distribution of each product

Note: sk $=$ skewness

\section{Empirical Results and Discussion}

\subsection{Empirical Results}

Table 1 shows the results of the stationary tests. It shows that all prices used in this study are not stationary level. Nevertheless, the unit root tests of ADF, Phillipe-Perron and KPSS on the first differences show that all series are integrated in order (I (1)). This shows that there is a risk of cointegration between producer prices and retail prices. Long-term relationships were estimated in this study and the stationary test of the error term was performed in order to validate each long-term relationship.

The results of unit root tests on error terms (Table 2) confirm the existence of a long-term relationship between: milk and butter prices, between milk and cheese prices, between prices pork and pork chops and between the prices of pork and bacon. 
Table 2. Stationarity tests

\begin{tabular}{|c|c|c|c|c|c|c|c|}
\hline & ADF test stat & PP test & KPSS test & ADF test & PP test & KPSS & \\
\hline producer price in log (pp) & \multicolumn{3}{|c|}{ Producer price in level } & \multicolumn{3}{|c|}{ Producer price in first difference } & $\mathbf{I}(\mathbf{1})$ \\
\hline Milk & -3.48 & $-23.96 * *$ & 1.65 & $-8.21 * * *$ & $-61.55 * * *$ & $0.03(>0.1)$ & $\mathbf{I}(\mathbf{1})$ \\
\hline Pork & -3.39 & -17.87 & 1.72 & $-5.77 * * *$ & $-47.91 * * *$ & $0.04(>0.1)$ & $\mathbf{I}(\mathbf{1})$ \\
\hline retail price in $\log (\mathbf{R P})$ & \multicolumn{3}{|c|}{ Retail price in level } & \multicolumn{3}{|c|}{ Retail price in first difference } & $\mathbf{I}(\mathbf{1})$ \\
\hline Butter & -3.45 & -19.89 & 2.04 & $-6.01 * * *$ & $-62.46 * * *$ & $0.03(>0.1)$ & $\mathbf{I}(\mathbf{1})$ \\
\hline Cheese & -2.67 & $-41.12 * * *$ & 0.9 & $-8.31 * * *$ & $-78.39 * * *$ & $0.09(>0.1)$ & $\mathbf{I}(\mathbf{1})$ \\
\hline Homogenous milk (H-milk) & -2.59 & -14.6 & 2.84 & $-6.14 * * *$ & $-52.53 * * *$ & $0.11(>0.1)$ & $\mathbf{I}(\mathbf{1})$ \\
\hline partially skimmed milk (PSM) & -2.07 & -10.85 & 2.46 & $-6.08 * * *$ & $-56.58 * * *$ & $0.13(>0.1)$ & $\mathbf{I}(\mathbf{1})$ \\
\hline Pork chop & -2.1 & -10.73 & 2.66 & $-6.95 * * *$ & $-57.03 * * *$ & $0.08(>0.1)$ & $\mathbf{I}(\mathbf{1})$ \\
\hline Pork bacon & -1.27 & -4.62 & 2.2 & $-5.26 * * *$ & $-56.84 * * *$ & $0.17(>0.1)$ & $\mathbf{I}(\mathbf{1})$ \\
\hline
\end{tabular}

(**) null hypothesis is rejected at 5\%; (***) null hypothesis is rejected at $1 \%$. In () is the KPSS test p-value

Table 3 presents the estimated parameters of the long-run elasticity. This latter suggests that, in the long-term, prices for butter and cheese increase by $0.38 \%$ and $0.27 \%$, respectively, as a result of a $1 \%$ increase in the milk producer price. Whereas, in the case of pork market, it is clear that, in the long-term, prices for pork chops and pork bacon increased by $0.45 \%$ and $0.50 \%$, respectively, following a $1 \%$ increase in the price of pork at the farm.

Table 3. Long-term elasticities between producers and retails prices, Engel and Granger cointegration test

\begin{tabular}{|c|c|c|c|c|c|c|}
\hline Variable & & $D_{t-1}=$ Milk pr & ducer price & & $P P_{t-1}=p o r$ & roducer price \\
\hline$R T$ (retail price) & Butter & Cheese & H-milk & PS-milk & Pork chop & Pork bacon \\
\hline Intercept & $-1.049 * *$ & -0.749 & $-4.150 * * *$ & $-2.596 * * *$ & $-0.933 * * *$ & $-1.979 * * *$ \\
\hline$P P_{t-1}$ & $0.381 * * *$ & $0.268 * * *$ & $0.750 * * *$ & $0.515 * * *$ & $0.452 * * *$ & $0.499 * * *$ \\
\hline Stationarity test & $\mathrm{ADF}(\mathrm{PP})$ & PP (KPSS) & $\mathrm{ADF}(\mathrm{PP})$ & $\mathrm{ADF}(\mathrm{PP})$ & $\mathrm{ADF}(\mathrm{PP})$ & $\mathrm{ADF}(\mathrm{PP})$ \\
\hline$e c t_{t-1}$ & $\begin{array}{l}-3.935 * * * \\
(-22.031 * *)\end{array}$ & $\begin{array}{l}-36.842 * * * \\
(0.226(>0.1))\end{array}$ & $\begin{array}{l}-3.249^{*} \\
(-17.58 *)\end{array}$ & $\begin{array}{l}-2.440 \\
(-14.028)\end{array}$ & $\begin{array}{l}-3.924 * * * \\
(-22.331 * *)\end{array}$ & $\begin{array}{l}-3.598 * * \\
(-20.475 * *)\end{array}$ \\
\hline
\end{tabular}

$(* *)$ and $(* * *)$ for the third and fourth rows mean significant respectly at $5 \%$ and $1 \%$. For the last row, $(* *)$ and $(* * *)$ mean the error correction term $\left(e c t_{t-1}\right)$ is stationary respectly at $5 \%$ and $1 \%$. PP indicates "Philippe Perron stationarity test" results, PS indicates "Partial Skimmed"

The results of Granger's causality test between the farm and retail prices presented in Table 4 show the direction of causality in their short-term dynamics. These results illustrate that the milk farm price Granger caused the prices of homogeneous milk and partially skimmed milk. However, the price of butter Granger caused the farm price of milk. In the pork products market, the results show that the price of pork Granger caused the prices of bacon and pork chops.

Table 4. Granger causality test

\begin{tabular}{lll}
\hline Null hypothesis & F-test statistics & Decision \\
\hline Milk does not Granger caused Butter & 1.493 & Milk does not Granger caused Butter \\
Butter does not Granger caused Milk & 0.478 & Butter does not Granger caused Milk \\
Milk does not Granger caused Cheese & 0.624 & Milk does not Granger caused Cheese \\
Cheese does not Granger caused Milk & $3.699^{* *}$ & Cheese Granger caused Milk \\
Milk does not Granger caused H-milk & $8.352^{* * *}$ & Milk Granger caused H-milk \\
H-milk does not Granger caused Milk & 0.090 & H-milk does not Granger caused Milk \\
Milk does not Granger caused PS-Milk & $6.832^{* * *}$ & Milk Granger caused PS-Milk \\
PS-Milk does not Granger caused Milk & 0.485 & PS-milk does not Granger caused Milk \\
Pork does not Granger caused Pork Chops & $6.405^{* *}$ & Pork Granger caused Pork chops \\
Pork Chops does not Granger caused Pork & 1.840 & Pork Chops does not Granger caused Pork \\
Pork does not Granger caused Pork Bacon & $6.544^{* *}$ & Pork Granger caused Pork Bacon \\
Pork Bacon does not caused Pork & 0.114 & Pork Bacon does not caused Pork \\
\hline
\end{tabular}

$(*),(* *)$ and $(* * *)$ indicate that the null hypothesis is rejected at respectively $10 \%, 5 \%$ and $1 \%$.

The analyses of the cointegration tests of Engel and Granger confirmed the presence of long-term relationships 
between farm prices and retail prices. However, this test rejects at the threshold of 5\% the existence of cointegration relations between the price of homogeneous milk and the price of milk in production. In addition, the test shows a long-term relationship between the price of partially skimmed milk and the milk price at production at the threshold of $10 \%$. These results show that all the conditions are satisfied for the estimation of the Error Correction Model (ECM). Threshold Autoregressive (TAR) models and the Momentum Autoregressive Threshold (MTAR) model were estimated to investigate the asymmetry of price transmission and the effect of the persistence of farm price shocks on the retail price. These estimates were based on prices that are threshold cointegrated. Table 5 illustrates the main results of these estimation.

Table 5. Econometrics models results

\begin{tabular}{|c|c|c|c|c|c|c|c|c|c|}
\hline \multicolumn{5}{|c|}{ Butter price on Milk farm price } & \multicolumn{5}{|c|}{ Cheese price on Milk farm price } \\
\hline Variables & ECM & Variables & TAR & MTAR & Variables & ECM & variables & TAR & MTAR \\
\hline Intercept & 0.001 & Intercept & -0.007 & -0.006 & Intercept & 0.001 & Intercept & $-0.009^{*}$ & $-0.008^{*}$ \\
\hline$\Delta P P_{t-1}$ & $-0.055^{*}$ & $\Delta P P_{t-1}+$ & 0.036 & 0.046 & $\Delta P P_{t-1}$ & 0.068 & $\Delta P P_{t-1}+$ & 0.226 & 0.253 \\
\hline$\Delta P P_{t-2}$ & $-0.150 *$ & $\Delta P P_{t-2}+$ & -0.090 & -0.083 & $\Delta R P_{t-1}$ & $-0.345 * *$ & $\Delta P P_{t-1^{-}}$ & -0.061 & -0.086 \\
\hline$\Delta R P_{t-1}$ & -0.009 & $\Delta P P_{t-1^{-}}$ & -0.086 & -0.099 & $e c t_{t-1}$ & $-0.319 * *$ & $\Delta R P_{t-1}+$ & 0.033 & 0.066 \\
\hline$\Delta R P_{t-2}$ & 0.029 & $\Delta P P_{t-2}-$ & $-0.230 *$ & $-0.239^{*}$ & & & $\Delta R P_{t-1^{-}}$ & $-0.683 * *$ & $-0.758 * * *$ \\
\hline \multirow[t]{6}{*}{$e c t_{t-1}$} & $-0.248 * *$ & $\Delta R P_{t-1}+$ & $0.372 *$ & $0.376^{*}$ & & & $e c t_{t-1}+$ & -0.175 & -0.299 \\
\hline & & $\Delta R P_{t-2}+$ & -0.015 & -0.021 & & & $e c t_{t-1^{-}}$ & -0.404 & -0.255 \\
\hline & & $\Delta R P_{t-1^{-}}$ & -0.605 & $-0.594 *$ & & & & & \\
\hline & & $\Delta R P_{t-2^{-}}$ & -0.051 & -0.020 & & & & & \\
\hline & & $e c t_{t-1}+$ & -0.111 & -0.191 & & & & & \\
\hline & & $e c t_{t-1^{-}}$ & $-0.307 * *$ & $-0.237 * *$ & & & & & \\
\hline \multicolumn{5}{|c|}{ Pork chops on pork farm price } & \multicolumn{5}{|c|}{ Pork bacon on Pork farm price } \\
\hline variables & ECM & Variables & TAR & MTAR & Variables & ECM & variables & TAR & MTAR \\
\hline intercept & $0.006^{* *}$ & Intercept & -0.007 & -0.005 & Intercept & $0.005^{*}$ & Intercept & -0.007 & -0.005 \\
\hline$\Delta P P_{t-1}$ & 0.046 & $\Delta P P_{t-1}+$ & $0.156^{* *}$ & $0.150^{* *}$ & $\Delta P P_{t-1}$ & 0.015 & $\Delta P P_{t-1}+$ & 0.061 & 0.108 \\
\hline$\Delta R P_{t-1}$ & -0.155 & $\Delta P P_{t-1^{-}}$ & -0.059 & -0.037 & $\Delta R P_{t-1}$ & 0.117 & $\Delta P P_{t-1^{-}}$ & -0.045 & -0.091 \\
\hline \multirow[t]{4}{*}{$e c t_{t-1}$} & $-0.109 * *$ & $\Delta R P_{t-1}+$ & 0.020 & -0.001 & $e c t_{t-1}$ & $-0.166 * *$ & $\Delta R P_{t-1}+$ & $0.333^{*}$ & $0.302 *$ \\
\hline & & $\Delta R P_{t-1^{-}}$ & $-0.487 *$ & $-0.472 *$ & & & $\Delta R P_{t-1^{-}}$ & -0.278 & -0.247 \\
\hline & & $e c t_{t-1}+$ & -0.086 & -0.043 & & & $e c t_{t-1}+$ & -0.096 & $-0.192 * *$ \\
\hline & & $e c t_{t-1^{-}}$ & $-0.169^{*}$ & $-0.157 * *$ & & & $e c t_{t-1^{-}}$ & $-0.279 * * *$ & $-0.160 * *$ \\
\hline
\end{tabular}

$(*),(* *)$ and $(* * *)$ mean significantly at respectively $10 \%, 5 \%$ and $1 \%$

The results of the Error Correction Model show that the prices of butter and cheese react symmetrically and significantly to the increase or the decrease of the same extend of the milk farm price. Indeed, the rate of adjustment (-0.2481) in the long-term equilibrium between the milk farm price and the price of butter is negative, less than one and significant at the 5\% threshold. The same result was found with the ECM model between the milk farm price and the price of cheese. These results associated with residual stationary validate the estimates of these ECM models. The results indicate that, in the long-term, delayed farm price values influence, at the threshold of $10 \%$, the butter retail price. However, the results show that in the short-term, the milk farm price does not significantly affect the current consumer price of cheese. The price of cheese in the previous period has a significant negative impact on its current price at the level of 5\%. The results of TAR model show that there is an asymmetry in the transmission of positive and negative shocks from milk farm prices on the price of butter and cheese. The results of the TAR between the price of milk and the price of butter indicate that only positive shocks on milk farm prices are transmitted significantly on the price of butter. The transmission of negative shocks on the price of butter is not significant. The results of MTAR confirm the above-mentioned results. Moreover, the estimates of these two models reject the assumption of asymmetry in the transmission of milk price shocks on the price of cheese.

Moreover, concerning the pork sector, all long-term equilibrium adjustment parameters between pork farm price and the price of pork chops, and pork prices and bacon prices are negative, less than one and statistically significant at the 5\% threshold. This suggests that the hypothesis of symmetry in the transmission of farm price shocks to prices of pork chops and pork bacon is validated with the ECM model. The investigation of asymmetry in the transmission of pork prices perturbations to the prices of pork chops and pork bacon gives controversial results compared to those of the ECM model. In fact, the results of these threshold cointegration models claim 
that there is an asymmetry in the transmission of prices on the pork market. This latter demonstrates that only increases in the pork farm price are transmitted significantly at the 5\% level on both the price of pork chops and the price of bacon. Moreover, the results of the MTAR model show that there is a transmission of negative shocks on pork farm price at the 5\% threshold on bacon prices. Therefore, the TAR model rejects the symmetrical price transmission between the producer price of pork and the prices of the two products, whereas the MTAR confirms this hypothesis only in the case of the price of bacon.

We investigated the type of transmission that exists in the short-term when there is a rise or a decrease in producer prices on consumer prices. The Fischer test was conducted to verify whether the positive shocks and the negative ones of the farm prices symmetrically influence retail prices. These results are presented in Table 6 .

Table 6. Test for equality between farmer price increase /decrease on retail price variation (Fischer Test)

\begin{tabular}{ccccccc}
\hline & \multicolumn{3}{c}{ Milk farm price } & \multicolumn{3}{c}{ Pork farm price } \\
\hline Test de Wald & Butter & Cheese & H-milk & PS-milk & Pork Chops & Pork bacon \\
\hline$\sum_{i=1} \beta_{i}^{+}=\sum_{i=1} \beta_{i}^{-}$ & 4.393 & 0.501 & 3.001 & 5.093 & 3.752 & 2.118 \\
& $(0.042)$ & $(0.479)$ & $(0.089)$ & $(0.028)$ & $(0.058)$ & $(0.152)$ \\
& $\mathrm{P}=2$ & $\mathrm{P}=1$ & $\mathrm{P}=1$ & $\mathrm{P}=1$ & $\mathrm{P}=1$ & $\mathrm{P}=1$ \\
\hline
\end{tabular}

$\mathrm{P}$ is the optimal lags for models, () represent the p-value of the F-test, PS indicates "Partial Skimmed"

The table 6 shows that there is an asymmetry in short-term price transmission between the milk farm price and, respectively, the price of butter and the price of partially skimmed milk at the 5\% threshold. This asymmetry is significant at the $10 \%$ level with the homogeneous milk price. Regarding the pork market, we found that the price transmission is asymmetrical in the short-term between the farm price of pork and the price of pork chops at the $10 \%$ threshold. The test illustrates that the effects of an increase and a decrease of farm prices on butter and bacon prices are symmetrical in the short-term.

\section{Discussions}

Our results show that dairy and pork prices in the retail market respond quickly to farm prices increasing rather than prices decreasing. As in the case of da Cunha and Wander (2014), this reaction of retail prices is more intense in the case of increase farm prices. Our results corroborate Awokuse and Wang (2009) findings evidence of asymmetric price transmission in the dairy sector in the United States. On the other hand, they differ from those of Bakucs and Ferto (2009) who found that the transmission is symmetric in the long-term in the pork sector and asymmetric in the short-term in Hungary. Our results show, however, an asymmetric transmission in the long-term, and a symmetric transmission in the short-term in the case of bacon. An asymmetric transmission is also found between the farm price of pork and the retail prices of pork chops.

We found asymmetric prices transmission between milk farm prices and consumer price of butter, and an asymmetric transmission between farm price of pork and the retail prices of pork chops and pork bacon. These results are consistent with the results of other studies found in the literature such as those of Stewart and Blayney (2012) for cheddar cheese in USA; Acosta and Valdés (2014) for the dairy sector in Panama; Kinnucan and Tadjion (2014) for the dairy sector in USA; Rosa, Waever and Vasciaveo (2015) for the dairy sector in Italy and Liu, Rabinowitz and Chen (2016) for the pork sector in USA. Similar results are found in different agri-food production chains such as wheat, corn and soybean in Brazil (Balcombe et al., 2007); in the rice value chain (Widyarini and Simatupang, 2013); in the aquatic products sector (Simioni et al., 2013); and in the potato sector (Assefa, Kuiper and Meuwissen, 2014).

The Granger causality test also showed that the causality is unidirectional from the milk farm prices to the consumer prices of partially skimmed milk and homogeneous milk. This can be explained by the fact that they are liquid milk products for consumption and require little processing of milk from the farm. On the other hand, another result is that butter price causes milk farm prices in the short-term. This result, which seems to be contrasted with the literature, is explained by the fact that the production of butter requires a large quantity of milk. While demand for butter in the retail market is rising sharply, processors will seek to increase butter production which will lead to an increase in demand for milk from the farm. Since on-farm production is limited by supply management quotas, this will result in an increase in the farm price of milk in subsequent periods.

The asymmetric price transmission in short-term was obtained with the Wald test between the farm price of milk and the retail price of butter, partially skimmed milk and homogeneous milk, respectively. This result was also obtained between the farm price of pork and the retail price of pork chops. Retail prices in the dairy and pork sectors respond differently both in the long-term and in the short-term as a result of an increase or decrease in 
farm prices. These results were found in the dairy sector in the US by Stewart and Blayney (2012); in Panama by Acosta and Valdés (2014), in Italy by Rosa, Waever and Vasciaveo (2015).

According to Bakucs, Falkowski and Ferto (2014) and Rabinowitz, Liu and Chen (2016) the concentration of agri-food markets favors asymmetric transmission of prices. They also argue that more restrictive regulation on the pricing mechanism, as in the case of Canada's dairy sector (Note 6), amplifies this effect. As a result, the asymmetry in the price transmission observed in the milk and pork sectors can be explained by the concentration of firms down the value chain. Our results confirm the effect of concentration on asymmetric price transmission. On the other hand, the amplification effect of price regulation is also observed. The rate of transmission of on-farm price increases is higher in the milk sector, which enjoys a more restrictive regulation on price control than in pork sector which is less regulated.

\section{Conclusion}

The issue of price transmission in the agri-food industries has been one of the major concerns of researchers in the literature over the last decade. The literature suggests that the concentration of agri-food markets, the holding of market power and government regulation as well as government support are the main factors behind the asymmetry of price transmission in these markets. In Canada, there is a high concentration of firms and a strong hold of market power by firms downstream of the value chain. In this article, we investigated the price transmission between producers and retailers in the dairy and pork sectors in Canada. The Granger causality test, the Engel and Granger cointegration test, and threshold error correction models (TAR and M-TAR) were used to answer this question. The monthly retail price data for butter, cheese, homogeneous milk, partly skimmed milk, pork bacon and pork chops and producer prices for milk and pork for the period 2010-2014 were used in the present investigation.

The results show that there is unidirectional causality from the farm price of milk to the retail prices of homogeneous milk and skimmed milk. On the other hand, the sense of causality is reversed with respect to butter The retail price of milk causes, in Granger's sense, the farm price of milk. In the pork market, the Granger test shows a causality of the price of pork from the farm toward the retail prices of pork chops and pork bacon. Our results show an asymmetric price transmission in short- and long-term between the farm price of milk and the retail price of butter. The same result is obtained between the farm price of pork and the retail prices of pork chops and pork bacon.

In contrast, the results show that the price transmission between milk production and cheese is symmetrical both in the short-term and in the long-term. There is no cointegration relationship between the farm price of milk and the retail prices of homogeneous milk and partially skimmed milk. Moreover, transmission is asymmetrical in the short-term between the price of milk on the farm and milk prices for consumption. These results generally show that consumer prices are responding more quickly to increasing farm prices than to decreasing prices. This dynamic of price transmission is strongly linked to the concentration of agri-food markets and in particular to the high concentration of processing and retail firms in these sectors. The detention of market power caused by this high concentration of firm leads to strong pressure from these firms in fixing the prices of food products. This transmission mechanism deteriorates consumer welfare to the benefit of retailers and processors as well as distributors.

Given that each province has its own agricultural policies in addition to federal agricultural policies, it will be interesting to study this mechanism by province to highlight the effects of these different provincial policies on the dynamics of price transmission.

\section{References}

Acosta, A., \& Valdés, A. (2014). Vertical Price Transmission of Milk Prices: Are Small Dairy Producers Efficiently Integrated Into Markets?. Agribusiness, 30, 56-63. https://doi.org/10.1002/agr.21357

Anders, S. M. (2008). Imperfect Competition in German Food Retailing: Evidence from State Level Data. Atl Econ J., 36, 441. https://doi.org/10.1007/s11293-008-9136-8

Asche, F., Jaffry, S., \& Hartmann, J. (2007). Price transmission and market integration: vertical and horizontal price linkages for salmon. Applied Economics, 39, 2535-2545. https://doi.org/10.1080/00036840500486524

Assefa, T. T., Kuiper, W. E., \& Meuwissen, M. P. (2014). The Effect of Farmer Market Power on the Degree of Farm Retail Price Transmission: A Simulation Model with an Application to the Dutch Ware Potato Supply Chain. Agribusiness, 30, 424-437. https://doi.org/10.1002/agr.21371

Assefa, T. T., Meuwissen, M. P., \& Lansink, A. G. O. (2016). A review of the effects of contextual factors on 
price volatility transmission in food supply chains. Agricultural Markets Instability: Revisiting the Recent Food Crises, 85.

Assefa, T. T., Meuwissen, M. P., \& Oude, L. A. (2013). Literature review on price volatility transmission in food supply chains, the role of contextual factors and the CAP's market measures. Working paper.

Atozou, B., \& Akakpo, K. (2017). Dynamic and Volatility of World Agricultural Market Prices: Impacts on Importations and Food Security in WAEMU. International Journal of Economics and Finance, 9(12), 180. https://doi.org/10.5539/ijef.v9n12p180

Atozou, B., \& Lawin, K. G. (2016). Impact of the Farm Income Stabilization Insurance Program on Production Decisions in the Quebec Pork Industry: An Empirical and Theoretical Analysis. Sustainable Agriculture Research, 5(4), 94. https://doi.org/10.5539/sar.v5n4p94

Awokuse, T. O., \& Wang, X. (2009). Threshold Effects and Asymmetric Price Adjustments in U.S. Dairy Markets. Canadian Journal of Agricultural Economics/Revue canadienne d'agroeconomie, 57, 269-286. https://doi.org/10.1111/j.1744-7976.2009.01151.x

Bakucs, L. Z., \& Fertö, I. (2009) Marketing and Pricing Dynamics in the Presence of Structural Breaks: The Hungarian Pork Market. Journal of International Food \& Agribusiness Marketing, 21, 116-133. https://doi.org/10.1080/08974430802587638

Bakucs, L. Z., \& Fertõ, I. (2005). Marketing margins and price transmission on the Hungarian pork meat market. Agribusiness, 21, 273-286. https://doi.org/10.1002/agr.20047

Bakucs, L. Z., \& Ferto, I. (2008). Price transmission on the Hungarian milk market, in: 2008 International Congress, August. pp. 26-29.

Bakucs, Z., Fałkowski, J., \& Fertö, I. (2014) Does Market Structure Influence Price Transmission in the Agro-food Sector? A Meta-Analysis Perspective. J Agric Econ., 65, 1-25. https://doi.org/10.1111/1477-9552.12042

Balcombe, K., Bailey, A., \& Brooks, J. (2007). Threshold Effects in Price Transmission: The Case of Brazilian Wheat, Maize, and Soya Prices. Am. J. Agr. Econ., 89, 308-323. https://doi.org/10.1111/j.1467-8276.2007. 01013.x

Ben-Kaabia, M., \& Gil, J. M. (2007). Asymmetric price transmission in the Spanish lamb sector. European Review of Agricultural Economics, 34, 53-80. https://doi.org/10.1093/erae/jbm009

Carman, H. F., \& Sexton, R. J. (2005) Supermarket fluid milk pricing practices in the western United States. Agribusiness, 21, 509-530. https://doi.org/10.1002/agr.20062

Chan, K. S. (1993). Consistency and limiting distribution of the least squares estimator of a threshold autoregressive model. The annals of statistics, pp.520-533. https://doi.org/10.1214/aos/1176349040

Chidmi, B., Lopez, R. A., \& Cotterill, R. W. (2005) Retail oligopoly power, dairy compact, and Boston milk prices. Agribusiness, 21, 477-491. https://doi.org/10.1002/agr.20058

Cutts, M., \& Kirsten, J. (2006) Asymmetric Price Transmission and Market Concentration: An Investigation into Four South African Agro-Food Industries. South African Journal of Economics 74, 323-333. https://doi.org/10.1111/j.1813-6982.2006.00064.x

da Cunha, C.A., and Wander, A.E. (2014). Asymmetry in farm-to-retail dry bean price transmission in Sāo Paulo, Brazil. Journal on Chain and Network Science, 14, 31-41. https://doi.org/10.3920/JCNS2014.0233

Dickey, D. A., \& Fuller, W. A. (1981). Likelihood ratio statistics for autoregressive time series with a unit root. Econometrica. Journal of the Econometric Society, 1057-1072. https://doi.org/10.2307/1912517

Enders, W., \& Siklos, P. L. (2001). Cointegration and threshold adjustment. Journal of Business \& Economic Statistics, 19, 166-176. https://doi.org/10.1198/073500101316970395

Engle, R. F., \& Granger, C. W. (1987). Co-integration and error correction: representation, estimation, and testing. Econometrica: journal of the Econometric Society, 251-276. https://doi.org/10.2307/1913236

Ewing, B. T., Payne, J. E., Thompson, M. A., \& Al-Zoubi, O. M. (2006). Government expenditures and revenues: Evidence from asymmetric modeling. Southern Economic Journal, 190-200. https://doi.org/10.2307/20111882

Falkowski, J. (2010). Price transmission and market power in a transition context: evidence from the Polish fluid milk sector. Post-communist economies, 22, 513-529. https://doi.org/10.1080/14631377.2010.518477 
Goodwin, B. K., \& Harper, D. C. (2000). Price transmission, threshold behavior, and asymmetric adjustment in the US pork sector. Journal of Agricultural and Applied Economics, 32, 543-553. https://doi.org/10.1017/S1074070800020630

Granger, C. W. (1988). Some recent development in a concept of causality. Journal of econometrics, 39(1), 199-211. https://doi.org/10.1016/0304-4076(88)90045-0

Heminthavong, K. (2015). Le mécanisme de la gestion de l'offre au Canada. Bibliothèque du Parlement= Library of Parliament.

Jensen, J. D., \& Møller, A. S. (2007). Vertical Price Transmission in the Danish food marketing chain. Citeseer.

Kim, H., \& Ward, R.W. (2013). Price transmission across the US food distribution system. Food policy, 41, 226-236. https://doi.org/10.1016/j.foodpol.2013.05.006

Kinnucan, H. W., \& Forker, O. D. (1987). Asymmetry in farm-retail price transmission for major dairy products. American journal of agricultural economics, 69, 285-292. https://doi.org/10.2307/1242278

Kinnucan, H. W., \& Tadjion, O. (2014). Theoretical Restrictions on Farm-Retail Price Transmission Elasticities: A Note. Agribusiness, 30, 278-289. https://doi.org/10.1002/agr.21362

Lass, D. A. (2005). Asymmetric response of retail milk prices in the northeast revisited. Agribusiness, 21, 493-508. https://doi.org/10.1002/agr.20061

Lippert, O. (2001). The perfect food in a perfect mess: The cost of milk in Canada. Fraser Institute.

Liu, Y., Rabinowitz, A., \& Chen, X. (2016). Heterogeneous Effects of Private Label and Branded Products on Farm-Retail Price Transmission: The Case of the US Fluid Milk Market, in: 2016 Annual Meeting, Boston, Massachusetts. Agricultural and Applied Economics Association.

MAPAQ, (2015). Monographie de l'industrie porcine au Québec. Bibliothèque et Archives nationales du Québec

Meyer, J., \& von Cramon-Taubadel, S. (2004) Asymmetric Price Transmission: A Survey. Journal of Agricultural Economics, 55, 581-611. https://doi.org/10.1111/j.1477-9552.2004.tb00116.x

Mighri, Z., \& Mansouri, F. (2015) Asymmetric price transmission within the Argentinean stock market: an asymmetric threshold cointegration approach. Empir Econ., 51, 1115-1149.

https://doi.org/10.1007/s00181-015-1029-5

Phillips, P. C., \& Perron, P. (1988). Testing for a unit root in time series regression. Biometrika, 75, 335-346. https://doi.org/10.1093/biomet/75.2.335

Rabinowitz, A., Liu, Y., \& Chen, X. (2016). The Impact of Price Regulations on Farm-Retail Price Transmission: The Case of Fluid Milk, in: 2016 Annual Meeting, San Antonio, Texas. Southern Agricultural Economics Association.

Reziti, I. (2015). Price transmission analysis in the Greek milk market. SPOUDAI-Journal of Economics and Business, 64, 75-86.

Rojas, C., Andino, A., \& Purcell, W. D. (2008) Retailers' response to wholesale price changes: new evidence from scanner-based quantity-weighted beef prices. Agribusiness, 24, 1-15. https://doi.org/10.1002/agr.20143

Rosa, F., Weaver, R. D., \& Vasciaveo, M. (2015). Structural Changes and Dairy Chain Efficiency in Italy. International Journal on Food System Dynamics, 6, 191-211.

Simioni, M., Gonzales, F., Guillotreau, P., \& Le Grel, L. (2013) Detecting Asymmetric Price Transmission with Consistent Threshold along the Fish Supply Chain. Canadian Journal of Agricultural Economics/Revue canadienne d'agroeconomie, 61, 37-60. https://doi.org/10.1111/j.1744-7976.2012.01257.x

Skogstad, G. (1993). Policy under siege: supply management in agricultural marketing. Canadian Public Administration, 36(1), 1-23. https://doi.org/10.1111/j.1754-7121.1993.tb02163.x

Stewart, H., \& Blayney, D. P. (2011). Retail dairy prices fluctuate with the farm value of milk. Agricultural and Resource Economics Review, 40, 201. https://doi.org/10.1017/S1068280500008017

Vavra, P., \& Goodwin, B. K. (2005). Analysis of Price Transmission Along the Food Chain (OECD Food, Agriculture and Fisheries Papers). Organisation for Economic Co-operation and Development, Paris.

von Cramon-Taubadel, S. (1998). Estimating asymmetric price transmission with the error correction representation: An application to the German pork market. European review of agricultural economics, 25, 
1-18. https://doi.org/10.1093/erae/25.1.1

Widyarini, M., \& Simatupang, T. M. (2013). An Adaptive Structuration Theory towards Price Transmission along Rice Value Chain. Abstract of Economic, Finance and Management Outlook 1.

\section{Notes}

Note 1. http://www.dairyinfo.gc.ca/index_f.php?s1=dff-fcil\&s2=proc-trans\&s3=kp-pc

Note 2. See Bakucs et al (2014) for meta-analysis on price transmission

Note 3. http://lactualite.com/assets/uploads/2015/12/2015-12-14-Prix-du-lait-fiche-techniqued\%C3\%A9tail-versionN1.pdf

Note 4. For more information visit La Presse website:

http://plus.lapresse.ca/screens/eb8c3814-38dc-454d-8b9b-9439d47c5478_7C_ _ 0. html

Note 5. La Presse website:

http://plus.lapresse.ca/screens/eb8c3814-38dc-454d-8b9b-9439d47c5478_ 7C__ 0.html

Note 6. Butter, cheese and fluid milk retail prices and support prices are set by the Canadian Dairy Commission (CDC). In Quebec, the province most specialized in dairy production in Canada, processors, distributors and retailers turn to the Régie des marchés agricoles et alimentaires du Québec (RMAAQ) to request an increase in drinking milk retail prices. Thus, through the supply management system, governments do not support the dairy sector, see http://lait.org/leconomie-du-lait/prix-du-lait/

\section{Copyrights}

Copyright for this article is retained by the author(s), with first publication rights granted to the journal.

This is an open-access article distributed under the terms and conditions of the Creative Commons Attribution license (http://creativecommons.org/licenses/by/4.0/). 